\title{
Genomic constancy during the development of Lathyrus odoratus cultivars
}

\author{
B. G. MURRAY, K. R. W. HAMMETT* \& LORRAINE S. STANDRING \\ Department of Botany, University of Auckland, and "DSIR Fruit and Trees, Private Bag, Auckland, New Zealand
}

\begin{abstract}
The sweet pea, Lathyrus odoratus, has a well-documented history of the development of its cultivars in various parts of the world. Measurements of genome size, using flow cytometry, and observations on the karyotypes, as well as the analysis of meiotic pairing of $F_{1}$ hybrids (between the wild sweet pea and two modern cultivars), all show that this development has not been accompanied by changes in karyotype or genome size. However, the cultivars do differ in pollen size and guard cell chloroplast number, both characteristics that have been suggested to be controlled by the nucleotype; however, this is clearly not the case in $L$. odoratus.
\end{abstract}

Keywords: cultivars, flow cytometry, genomic constancy, Lathyrus odoratus.

\section{Introduction}

The differences between cultivated plants and their wild ancestors are usually striking and come about through selection for specific characters and as correlated responses to this selection. Many different character changes have been catalogued and include obvious features such as an increase in the size of specific organs, loss of dispersal mechanisms and changes in the breeding system (Pickersgill \& Heiser, 1976). In addition there can be cryptic changes such as the alteration of chromosome structure and number. To some extent, however, this sort of change is constrained by the mode of reproduction of the crop; vegetative reproduction facilitates evolution via chromosome changes, such as aneuploidy, that reduce fertility. In Hyacinthus orientalis Darlington et al. (1949) were able to show a progressive increase in chromosome number with time and a similar story has been described by Brandham (1986) in Narcissus subgenus Narcissus. In both these exaples there is an increase in chromosome number/genome size correlated with the development of new cultivars. Nevertheless, as Brandham (1986) points out, other genera with many similar features (e.g. Tulipa) have not followed this pattern. An alternative mechanism for increasing genome size without a change in chromosome number has been found in North American populations of Zea mays. Both Laurie \& Bennett (1985) and Rayburn et al (1989) have found a significant variation in nuclear DNA content, of the order of 38 per cent, without any change in chromosome number.
L. odoratus has a limited natural distribution in Sicily and Sardinia (Dicks, 1900). It is known to have been introduced into cultivation in England in 1699 and to Holland at about the same time. Variation in the cultivated sweet pea has arisen entirely by gene mutation and subsequent hybridization within the species (Crane \& Lawrence, 1938). Mutations that affect flower colour, flower shape, plant habit and time of flowering have occurred, giving rise to many distinct cultivars.

These mutations have been developed into a very large numer of cultivars in diverse parts of the world, such as Britain, U.S.A. and Australia. In the different areas selection has been for different characteristics yielding the huge diversity in cultivars available today.

Feulgen microdensitometry has been the most frequently used technique to measure genome size in plants but in recent years there has been an increase in the use of flow cytometry together with fluorescent dyes such as propidium iodide, mythramicin and DAPI (4',6-diamidino-2-phenylindole), for this purpose. This has followed the publication of a simple protocol showing that plant nuclei, isolated by mechanical chopping of plant tissue, can readily be used for the flow cytometric determination of plant genome size (Galbraith et al., 1983). These techniques allow the rapid and accurate determination of plant nuclear DNA amounts based on a large number of nuclei (usually 10,000). There appear to be only two reports of the use of flow cytometry to measure intraspecific variation in nuclear DNA amount (Rayburn et al., 1989; Rayurn \& Auger, 1990). Both of these involve 
Zea mays and show that the technique can readily be used to detect this sort of variation. Within the genus Lathyrus there have been several reports of large interspecific differences in DNA content (see Rees \& Hazarika, 1969 and Narayan, 1982). In addition, Sharma \& Datta (1959) and Roy \& Singh (1967), for example, have reported considerable karyotype variation within the cultigen $L$. odoratus including large differences in total chromosome length.

Many changes in plant cell size have been attributed to the nucleotypic as opposed to the genotypic effects of DNA amount (Bennett, 1972, 1987) including pollen size and chloroplast number in guard cells. In many genera these parameters have been shown to be correlated with increases in genome size (Butterfass, 1979) but a causal relationship has not been demonstrated. Recently several observations have led us to question such a causal relationship as we have found that different chromosomes have specific effects on guard cell chloroplast number in the genus Cyphomandra (Standring et al., 1990). Trisomic addition lines of $C$. betacea were found to have chloroplast numbers that ranged from the value of the diploid through to that of induced triploids, despite the fact that the different chromosomes that were added were of very similar size. In Lolium perenne, Francis et al. (1990) have shown that colchicine can induce heritable changes in cell size and chloroplast number per cell without any alteration to chromosome number. Thus care must be taken with the use of these sorts of characters to predict differences in genome size in plants.

As part of a wider study of the genus Lathyrus, it was seen that the well-recorded history of the development of the sweet pea and the large number of cultivars available, offered the opportunity to investigate the cytological changes associated with the development of the cultivars.

\section{Materials and methods}

The cultivars used in this study were selected from a much larger collection of authenticated cultivars so as to provide representative genotypes developed at different times and in different places (Table 1).

The methods for preparing karyotypes, meiotic spreads and the production of hybrids are outlined in Murray \& Hammett (1989). Nucleolar organizer regions were identified by silver staining of air-dried chromosome preparations (Geber \& Schweizer, 1988) following the staining schedule of Hizume et al. (1980).

To measure nuclear DNA amounts, isolated nuclei were prepared by chopping leaves with razor blades (Galbraith et al., 1983) in the extraction buffer of de
Laat \& Blaas (1984) modified by the substitution of 10 mM sodium dithionite for dithiothreitol as this was found to be more effective in controlling oxidative processes. Leaf material $(0.1 \mathrm{~g})$ was used with $3 \mathrm{ml}$ of the extraction buffer. The chopped material was filtered through 63- and $16-\mu \mathrm{m}$ nylon mesh filters and stained with DAPI (Sigma) to give a final stain concentration of $10 \mu \mathrm{g} / \mathrm{ml}$. Measurements were made on a BectonDickinson FACS440 flow cytometer equipped with a Coherent Innova Argon laser using a $488 \mathrm{~nm}$ laser line operating at $275 \mathrm{~mW}$. Ten thousand nuclei were measured from each sample and each cultivar was examined on at least two separate occasions. In order to calibrate the measurements from the flow cytometer and minimize variation between runs, two standards [Triticum aestivum cv. Chinese Spring and Hordeum vulgare cv. Sultan with $34.63 \mathrm{pg}$ and $11.12 \mathrm{pg}$ DNA per 2C nucleus respectively (Bennett, et al., 1982)] were included along with the wild type $L$. odoratus ('Original') with each replicate. A typical graph for one of the $L$. odoratus cultivars is shown in Fig. 1. The coefficient of variation (cv) of the $2 \mathrm{C}$ peak, calculated using the formula of Thornthwaite et al. (1980) is 0.69 per cent and in our material the cv was typically less than 1 per cent and never more than 2 per cent.

Chroloplast numbers were counted in 40 guard cells from the lower epidermis of fully expanded leaves. A preliminary study showed that the variation in chloroplast number in different mature leaves along a stem was not significant when analysed by ANOVA $(F=4.982,0.0001<P \leq 0.005)$. Epidermal strips were mounted in a 1 per cent aqueous solution of silver nitrate and the chloroplasts stain brown after a short period of time. The polar diameter of 30 pollen grains per cultivar was measured after mounting fresh pollen in cotton blue in lacto-phenol (Darlington \& LaCour, 1976).

\section{Results}

The karyotypes of the 20 cultivars examined all appear similar and consist of one pair of small metacentric chromosomes, one pair of large sub-metacentric chromosomes and five pairs of acrocentric chromosomes. Secondary constrictions were not observed in any of the chromosomes but the sites of the nucleolar organizer region have been established, using silver staining, as terminal on two of the acrocentric pairs. In the $F_{1}$ hybrids between 'Original' and the two modern cultivars 'Hunters Moon' and 'Gloria', there were no obvious differences in the size of homologous chromosomes. The meiotic behaviour of both these hybrids was completely regular. At pachytene it was not possible to trace all the chromosomes in any one nucleus, 
Table 1 List of cultivars of $L$. odoratus used in this paper with their origin, number of chloroplasts/guard cell, pollen diameter, $2 \mathrm{C}$ nuclear DNA amount and whether they have been karyotyped

\begin{tabular}{|c|c|c|c|c|c|c|c|c|c|}
\hline Number & Cultivar & Introduction & $\mathrm{G} / \mathrm{S}$ & $\mathrm{W} / \mathrm{S} / \mathrm{L}$ & Origin & $\begin{array}{l}\text { Chloroplast } \\
\text { number }\end{array}$ & $\begin{array}{l}\text { Pollen } \\
\text { diameter } \\
(\mu \mathrm{m})\end{array}$ & $\begin{array}{l}2 \mathrm{C} \text { DNA } \\
\text { content } \\
(\mathrm{pg})\end{array}$ & Karyotype \\
\hline 1 & Original & $1699^{*}$ & $\mathrm{G}$ & $\mathbf{L}$ & Med & 9.11 & 82.90 & 15.93 & + \\
\hline 2 & Chiltern Matucana & $\mathrm{C} 18 ?$ & $\mathrm{G}$ & $\mathrm{L}$ & $\mathrm{SA} \infty$ & 8.55 & & & \\
\hline 3 & Maishman Matucana & $\mathrm{C} 18 ?$ & $\mathrm{G}$ & $\mathrm{L}$ & $\mathrm{SA} \infty$ & 9.15 & 90.00 & & \\
\hline 4 & Painted Lady & C18? & G & $\mathrm{S}$ & $\mathrm{SA} \infty$ & 8.63 & & & \\
\hline 5 & Quito & C18? & G & L & $S A \infty$ & 9.05 & & 16.04 & + \\
\hline 6 & Lady Serena James & 1868 & G & $\mathrm{L}$ & B & 8.03 & & & \\
\hline 7 & Pink Cupid & 1895 & $\mathrm{G}$ & $\mathrm{S}$ & USA & & & & + \\
\hline 8 & Prima Donna & 1896 & $\mathrm{G}$ & $\mathrm{L}$ & B & 8.48 & & & \\
\hline 9 & America & 1898 & G & $\mathrm{L}$ & USA & 9.65 & 87.40 & 15.93 & + \\
\hline 10 & Miss Willmott & 1901 & $\mathrm{G}$ & $\mathrm{L}$ & B & 10.43 & & & + \\
\hline 11 & Dorothy Eckford & 1903 & G & $\mathrm{L}$ & B & 9.15 & 94.80 & 15.54 & \\
\hline 12 & Janet Scott & 1903 & $\mathrm{G}$ & $\mathrm{L}$ & B & 9.40 & & & \\
\hline 13 & King Edward VII & 1903 & $\mathrm{G}$ & $\mathrm{L}$ & B & 10.08 & 89.40 & & \\
\hline 14 & Lord Nelson & 1907 & G & $\mathrm{L}$ & B & 8.95 & & & \\
\hline 15 & Mrs Collier & 1907 & $\mathrm{G}$ & $\mathrm{L}$ & B & 9.70 & & & \\
\hline 16 & American Beauty & 1920s? & $\mathrm{S}$ & W & USA & 10.70 & & & \\
\hline 17 & Fantasy & 1931 & $\mathrm{~S}$ & $\mathrm{~L}$ & B & 10.03 & & & \\
\hline 18 & Mrs Douglas MacArthur & $1940 \mathrm{~s}$ & $\mathrm{~S}$ & W & USA & 9.60 & & 16.43 & \\
\hline 19 & Gaiety & 1946 & S & $\mathrm{L}$ & B & 9.00 & 91.80 & & \\
\hline 20 & Pixie & 1952 & $\mathrm{~S}$ & $\mathrm{~L}$ & B & 10.05 & 85.10 & & \\
\hline 21 & Coquette & 1953 & $S$ & $\mathrm{~L}$ & B & 11.30 & & & \\
\hline 22 & Jester & 1953 & $\mathrm{~S}$ & $\mathrm{~L}$ & B & 11.23 & & 16.16 & + \\
\hline 23 & Twink & 1953 & S & $\mathrm{L}$ & B & 9.68 & & & \\
\hline 24 & Ink Splash & 1956 & $S$ & $\mathrm{~L}$ & B & 9.83 & 85.60 & & + \\
\hline 25 & Chigasaki \# 11 & $1960 \mathrm{~s}$ & S & W & $\mathbf{J}$ & 10.10 & 85.70 & 15.93 & \\
\hline 26 & Diana & $1960 \mathrm{~s}$ & $\mathrm{~S}$ & W & USA & 9.28 & & 16.19 & \\
\hline 27 & Gloria & $1960 \mathrm{~s}$ & $\mathrm{~S}$ & W & USA & 10.63 & 89.10 & 15.70 & \\
\hline 28 & Marilyn & $1960 \mathrm{~s}$ & $\mathrm{~S}$ & W & USA & 12.48 & & 15.94 & \\
\hline 29 & Ballerina & 1960s? & $\mathrm{S}$ & W & A & 9.78 & & 15.96 & + \\
\hline 30 & Beverly Kay & 1960s? & S & W & A & 9.70 & & & \\
\hline 31 & Christine Martin & 1960s? & S & W & A & 10.68 & & & + \\
\hline 32 & Fragrance & 1960s? & S & W & A & 10.85 & & & + \\
\hline 33 & Piralilla Cream & 1960s? & $\mathrm{S}$ & W & A & & & & + \\
\hline 34 & White Gem & 1960s? & $S$ & W & A & 10.36 & 83.30 & & + \\
\hline 35 & Herald & 1962 & $\mathrm{~S}$ & L & B & 10.30 & & & \\
\hline 36 & Gipsy Queen & 1965 & S & $\mathbf{L}$ & B & 12.15 & & & \\
\hline 37 & Hunters' Moon & 1968 & $\mathrm{~S}$ & $\mathbf{L}$ & B & 11.20 & 86.30 & 16.21 & \\
\hline 38 & Apricot Queen & 1972 & $\mathrm{~S}$ & $\mathrm{~L}$ & B & 12.10 & & 15.97 & + \\
\hline 39 & Southbourne & 1972 & $\mathrm{~S}$ & $\mathrm{~L}$ & B & 10.00 & & & + \\
\hline 40 & Eva Bridger & 1978 & $S$ & $\mathbf{L}$ & $\mathrm{NZ}$ & & & & + \\
\hline 41 & Mrs B. Jones & 1978 & S & $\mathrm{L}$ & B & 10.38 & & & + \\
\hline 42 & Karen Reeve & 1980 & S & $\mathrm{L}$ & B & 10.75 & & & \\
\hline 43 & Lady Diana & 1981 & $\mathrm{~S}$ & L & B & 11.30 & & & + \\
\hline 44 & North Shore & 1982 & $\mathrm{~S}$ & $\mathrm{~L}$ & B & & & & + \\
\hline 45 & Mammoth Lavender & 1982 & $S$ & $\mathrm{~S}$ & USA & 10.35 & & & \\
\hline 46 & Mammoth Mid Blue & 1982 & $S$ & $\mathrm{~S}$ & USA & 10.40 & & 16.49 & + \\
\hline 47 & Mammoth Salmon Pink & 1982 & $S$ & $\mathrm{~S}$ & USA & 9.98 & & & + \\
\hline 48 & Bridgewater Boy & 1984 & $\mathrm{~S}$ & $\mathrm{~L}$ & B & 10.95 & & & \\
\hline 49 & Duchess of Roxburghe & 1984 & $\mathrm{~S}$ & $\mathrm{~L}$ & B & 11.55 & & & \\
\hline 50 & Anniversary & 1985 & $\mathrm{~S}$ & $\mathrm{~L}$ & B & 11.03 & & & \\
\hline 51 & Just William & 1988 & $\mathrm{~S}$ & $\mathrm{~L}$ & B & 11.90 & 88.90 & 16.36 & \\
\hline 52 & E8B & - & $\mathrm{S}$ & $\mathrm{S}$ & $\mathrm{NZ}$ & 9.95 & 91.80 & & \\
\hline
\end{tabular}


Table 1 Continued

\begin{tabular}{|c|c|c|c|c|c|c|c|c|c|}
\hline Number & Cultivar & Introduction & $\mathrm{G} / \mathrm{S}$ & $\mathrm{W} / \mathrm{S} / \mathrm{L}$ & Origin & $\begin{array}{l}\text { Chloroplast } \\
\text { number }\end{array}$ & $\begin{array}{l}\text { Pollen } \\
\text { diameter } \\
(\mu \mathrm{m})\end{array}$ & $\begin{array}{l}\text { 2C DNA } \\
\text { content } \\
\text { (pg) }\end{array}$ & Karyotype \\
\hline 53 & Purple Flake & $\bullet$ & S & $\mathrm{L}$ & NZ & 9.15 & 81.40 & 16.32 & \\
\hline 54 & $\mathrm{E} 8 \mathrm{~B} \times$ Gloria $\mathrm{F}_{1}$ & & $\mathrm{~S}$ & W & $\mathrm{NZ}$ & & 87.40 & & \\
\hline 55 & Gloria $\times$ Original $F_{1}$ & & G & L & NZ & 8.38 & & 16.10 & \\
\hline 56 & Original $\times$ Hunters' Moon $F_{1}$ & & $\mathrm{G}$ & $\mathrm{L}$ & NZ & & & 15.82 & \\
\hline
\end{tabular}

* Introduced to Britain 1699, but natural species.

? Date of introduction to decade or century.

- Recent hybrid involving ancestral and more recent cultivars.

G Grandiflora flower form with clamped keel.

S Spencer flower form with open keel.

W Winter flowering.

S Spring flowering.

L Late or summer flowering.

A Australia.

$\begin{array}{ll}\text { B } & \text { Britain. } \\ \text { J } & \text { Japan, but selection from USA cultivars. } \\ \text { Med } & \text { Mediterranean. } \\ \text { NZ } & \text { New Zealand. } \\ \text { SA } \infty & \begin{array}{l}\text { South America. These cultivars are purportedly } \\ \text { early variants of the original species and may } \\ \text { have been taken to South American by Spanish } \\ \\ \text { colonists. }\end{array} \\ \text { USA } & \text { United States of America. }\end{array}$

but where the chromosomes could be clearly seen there was no sign of buckles, unpaired regions or any other irregularity (Fig. 2a). At metaphase I seven bivalents were formed in all cells and their structure appeared completely normal (Fig. 2b).

Figure 1 shows the flow cytometric analysis of leaf nuclei from the cultivar 'Quito'. There are clear $2 \mathrm{C}$ and $4 \mathrm{C}$ peaks, the latter being at double the channel number of the former. The majority of nuclei are at the $2 \mathrm{C}$ stage and typically 7-8 per cent of the nuclei are found in the $2 \mathrm{C}$ peak channel. The mean value for all the cultivars is $16.11 \mathrm{pg} / 2 \mathrm{C}$ nucleus with a range of 15.54 to 16.43 (Table 1 ). The variation between runs for any one cultivar was usually small and less than 5 per cent. The measurements of nuclear DNA amounts confirm the above observations on the karyotypes with no differences being observed between the cultivars.

Unlike the measurements of DNA amount, those of pollen diameter showed considerable variation between cultivars (Table 1) ranging from $81.4 \mu \mathrm{m}$ in 'Purple Flake' to $94.8 \mu \mathrm{m}$ in 'Dorothy Eckford'. An analysis of variance shows that the differences between cultivars are highly significant $(F=50.52, P \leq 0.0001)$, however the correlation between pollen size and date of first release or appearance of the cultivars is not significant. It is interesting that the hybrid between 'E8B' and 'Gloria' has a smaller pollen diameter than either of its parents. There is also considerable variation in guard cell chloroplast number between cult-
Fig. 1. Flow cytometric analysis of the fluorescence of DAPI stained nuclei from leaves of $L$. odoratus cv. Quito 


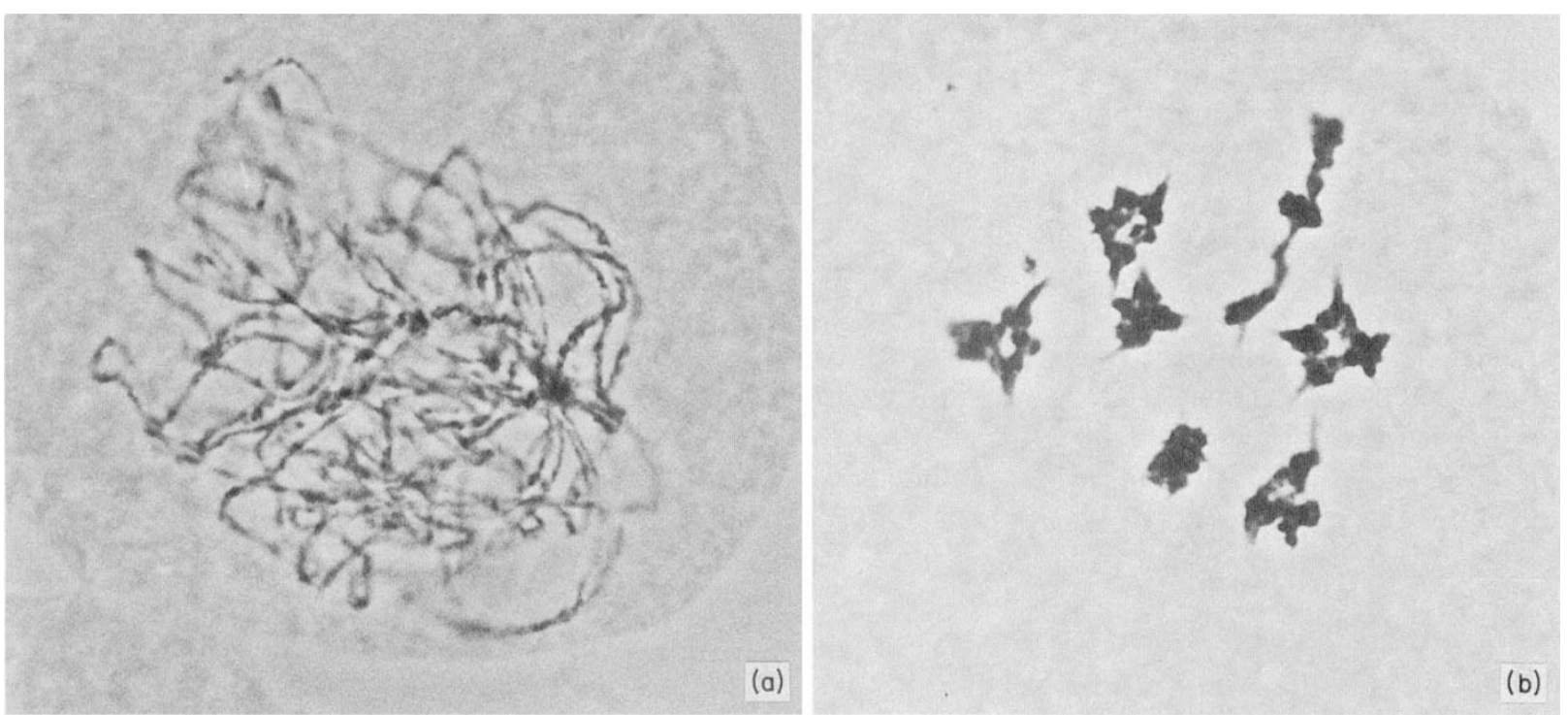

Fig. 2 Meiosis in the $F_{1}$ hybrid between $L$. odoratus cv. Gloria and cv. Original, (a) pachytene and (b) metaphase I.

ivars, with the lowest value (8.03) being found in 'Lady Serena James' and the highest (12.48) in 'Marilyn'. Unlike the pollen size variation, there is a clearer pattern to the variation in guard cell chloroplast number in relation to the chronological age of the cultivars. In that the development of the sweet pea has essentially taken place since 1868 , it is most relevant to restrict the comparison of chloroplast number with the date of release or first appearance of the cultivar to this time frame. The correlation between these two parameters is positive and significant $(n=42, r=0.647, P<0.001)$.

\section{Discussion}

Cultivated plants provide a useful resource to observe evolutionary change over a short period of time, since their history, as is the case in L. odoratus, is often well documented. In $L$. odoratus there have been striking changes in plant morphology, particularly in the size, shape and colour of flowers but we have not found any evidence of changes in chromosome structure or genome size associated with this diversity of floral form. Our observations do not support those of Sharma \& Datta (1959) who claimed large differences in total chromosome length between a range of cultivars. These differences appear difficult to reconcile. Of their 14 cultivars, two, 'Mariner' and 'Oriental', had larger chromosome complements than the others, and in addition they were recorded as having 'deep blue' and 'deep primrose' coloured flowers respectively (Sharma \& Datta, 1959). Although long desired, these colours have not been recorded in $L$. odoratus cultivars (Lawrence, 1939). Sharma \& Datta (1959) also reported that their cultivars had a range of different karyotypes with eight different types of chromosome with secondary constrictions. Our cultivars show no secondary constrictions as the nucleolar organizer regions are located at or very near to the ends of their chromosomes, however, we have found a wide range of NOR chromosome types in a study of almost 50 other Lathyrus species (B. G. Murray and K. R. W. Hammett, unpublished data). Thus, in the absence of voucher herbarium specimens, there must be doubt as to the identity of at least some of the material studied by Sharma \& Datta (1959).

Roy \& Singh (1967) compared the karyotypes of an unnamed cultivar from India with that of another unnamed cultivar from Britain. They claim that the Indian and British cultivars are karyotypically similar although they do differ in chromosome size. In addition the Indian material is reported to be very similar in karyotype to $L$. sativus, a blue-flowered species. We have examined several accessions of $L$. sativus all of which are clearly different to our $L$. odoratus cultivars. As our range of cultivars does not include any from India, we cannot exclude the possibility that those cultivars represent a separate line of development that is karyotypically different. We have, however, examined a wide range of cultivars from Europe, North America, Australia and New Zealand and have demonstrated that they are karyotypically very similar.

Our results indicate that the modern sweet pea is a species that has, in cultivation, been modified to show considerable morphological and physiological variation without any change in chromosome structure or genome size. In this respect $L$. odoratus differs greatly from Hyacinthus (Darlington et al., 1949) and Narcissus (Brandham, 1986), which show clear 
patterns of increasing chromosome number with the development of new cultivars or from Zea mays, which had developed with an accompanying amplification of its genome without a change in chromosome number (Rayburn \& Auger, 1990). Differences in the breeding system can, at least in part, explain the difference in cultivar evolution between Hyacinthus, etc., and Lathyrus in that the former group is perennial and frequently propagated vegetatively whereas Lathyrus is annual and seed propagated. It does not, however, offer any explanation for the difference from Zea and the karyotype stability in $L$. odoratus is also interesting in the light of recent evidence for rapid genomic change at the molecular level in plants (Walbot \& Cullis, 1985; Dover, 1988; John \& Miklos, 1988). It remains to be seen how much change at the molecular level has occurred during the short period of development of this species as a crop.

Despite the uniformity of karyotype and nuclear DNA amount in these sweet pea cultivars, they do differ in several other cellular parameters such as pollen size and guard cell chloroplast number. It has been suggested that both of these parameters are under nucleotypic control (Bennett, 1972; Butterfass, 1973) and therefore should not vary between cultivars with uniform karyotypes. The observation that they do vary, clearly suggests that this relationship cannot hold for all cases and there are probably several inter-related control factors. For example, Francis et al. (1990) have shown that colchicine-treated plants of Lolium perenne, which remain diploid after treatment, can show heritable changes in both cell size and chloroplast number. Furthermore, John \& Miklos (1988) point out the example of the moss, Bryum caespiticium, which underwent a 50 per cent decrease in cell volume in an 11-year period following a doubling of its chromosome number, thus illustrating that cell size can alter quite independently of genome size. We have also found that primary trisomics of Cyphomandra betacea can have very different guard cell chloroplast numbers (Standring et al., 1990). Some trisomics have chloroplast numbers that are not significantly different from the diploid whereas others are not significantly different from the autotriploid, clearly showing that there can be chromosome-specific effects on cellular parameters such as chloroplast number.

\section{Acknowledgements}

We would like to thank Nick Birchall and Ding Yi Xu, Department of Molecular Medicine, Auckland University Medical School, for their help with the flow cytometry and John Maindonald, DSIR, for statistical advice.

\section{References}

BENNETT, M. D. 1972. Nuclear DNA content and minimum generation time. Proc. R. Soc. Lond. B., 181, 109-135.

BENNETT, M. D. 1987. Variation in genomic form in plants and its ecological implications. New Phytol., 106 (Suppl.), 177-200.

BENNETT, M. D., SMITH, J, B. AND HESLOP-HARRISON, J. S. 1982. Nuclear DNA amounts in angiosperms. Proc. $R$. Soc. London. B., 216, 179-199.

BRANDHAM, P. E. 1986. Evolution of polyploidy in cultivated Narcissus subgenus Narcissus. Genetica, 68, 161-167.

BUTTERFASS, T. 1973. Control of plastid division by means of nuclear DNA amount. Protoplasma, 76, 167-195.

BUTTERfass, T. 1979. Patterns of Chloroplast Reproduction: $A$ Developmental Approach to Protoplasmic Plant Anatomy. Cell Biology Monographs, Vol. 6. Springer-Verlag, Wien.

CRANE, M. B. AND LAWRENCE, w. J. C. 1938. The Genetics of Garden Plants. Macmillan \& Co., London.

DARLINGTON, C. D., HAIR, J. B. AND HURCOMBE, R. 1949. The history of the garden hyacinths. Heredity, 5, 233-253.

DARLington, C. D. AND LACOUR, L. F. 1976. The Handling of Chromosomes. Allen and Unwin, London.

DE LAAT, A. M. M. AND BLAAS, J. 1984. Flow cytometric characterization and sorting of plant chromosomes. Theor. Appl. Genet., 67, 463-467.

DICKs, s. B. 1900. The early history of sweet peas. In: The Sweet Pea Bicentenery-Celebration - Report of the Celebration of the Bicentenary of the Introduction of the Sweet Pea into Great Britain. London. pp. 17-22.

DOVER, G. A. 1988. The new genetics. In: Prospects in Systematics, Hawkesworth, D. L. (ed), Clarendon Press, Oxford, pp. 151-168.

FRANCIS, A., JONES, R. N., PARKER, J. S. AND POSSELT, U. K. 1990. Colchicine-induced heritable variation in cell size and chloroplast numbers in leaf mesophyll cells of diploid ryegrass (Lolium perenne L.). Euphytica, 49, 49-55.

GALBRAITH, D. W., HARKINS, K. R., MADDOX, J. M., AYRES, N. M., SHARMA, D. P. AND FIROOZABADY, E. 1983. Rapid flow cytometric analysis of the cell cycle in intact plant tissues. Science, 220, 1049-1051.

GEBER, G. AND SCHWEIZER, D, 1988. Cytochemical heterochromatin differentiation in Sinapis alba (Cruciferae) using a simple air-drying technique for producing chromosome spreads. Pl. Syst. Evol., 158, 97-106.

HiZUME, M., SATO, S. AND TANAKA, A. 1980. A highly reproducible method of nucleolus organizing region staining in plants. Stain Technol., 55, 87-90.

JOHN, B. AND MikLOS, G. L. G. 1988. The Eukaryote Genome in Development and Evolution. Allen and Unwin, London.

LAURIE, D. A. AND BENNETT, M. D. 1985. Nuclear DNA content in the genera Zea and Sorghum. Intergeneric, interspecific and intraspecific variation. Heredity, 55, 307-313.

LAWRENCE, w. J. C. 1939. Crossing the sweet pea with other species - disappointing results. In: Sweet Pea Annual 1939, Glanville, S. J. (ed), The National Sweet Pea Society, London. pp. 13-14.

MURRAY, B. G. AND HAMMETT, K. R. w. 1989. Lathyrus chloranthus $\times$ L. chrysanthus: A new interspecific hybrid. Bot. Gaz., 
150, 469-476.

NARAYAN, R. K. J. 1982. Discontinuous DNA variation in the evolution of plant species: The genus Lathyrus. Evolution, 36, 877-891.

PICKERSGILL, B. AND HEISER, C. B. 1976. Cytogenetics and evolutionary change under domestication. Phil. Trans. R. Soc. London. B, 275, 55-69.

RAYBURN, A. L. AND AUGER, J. A. 1990. Genome size variation in Zea mays ssp, mays adapted to different altitudes. Theor. Appl. Genet., 79, 470-474.

RAYBURN, A. L., AUGER, J. A., BENZINGER, E. A. AND HEPBURN, A. G. 1989. Detection of intraspecific DNA content variation in Zea mays L. by flow cytometry. J. Exp. Bot., 40, $1179-1183$.

REES, H. AND HAZARIKA, M. H. 1969. Chromosome evolution in
Lathyrus. Chromosomes Today, 2, 158-165.

RoY, R. P. AND SINGH, M. K. 1967. Cytological studies in the genus Lathyrus Linn. J. Cytol. Genet., 2, 128-140.

SHARMA, A. K. AND DATTA, P. C. 1959. Application of improved technique in tracing karyotype differences between strains of Lathyrus odoratus L. Cytologia, 24, 389-402.

STANDRING, L. S., PRINGLE, G. J. AND MURRAY, B. G. 1990. The control of chloroplast numbers in Solanum muricatum Ait. and Cyphomandra betacea (Cav.) Sendt. and its value as an indicator of polyploidy. Euphytica, 47, 71-77.

THORNTHWAITE, J. T., SUGARBAKER, E. V. AND TEMPLE, W. J. 1980. Preparation of tissues for DNA flow cytometric analysis. Cytometry, 1, 229-237.

WALBOT, v. AND CULLIS, C. A. 1985. Rapid genomic change in higher plants. Ann. Rev. Pl. Physiol., 36, 367-396. 